\title{
QUANTIFYING BINOMINAL CONSTRUCTIONS IN PORTUGUESE AND RUSSIAN: THE CASE OF UM MONTE DE NP AND KUCHA NPGEN
}

\section{CONSTRUÇÕES BINOMINAIS QUANTIFICADORAS EM PORTUGUÊS E RUSSO: O CASO DE UM MONTE DE SN E KUCHA SNGEN}

\author{
Karen Sampaio Braga Alonso \\ Lattes | karensampaio@letras.ufrj.br \\ Universidade Federal do Rio de Janeiro \\ Diego Leite de Oliveira \\ Lattes | diegooliveira@letras.ufrj.br \\ Universidade Federal do Rio de Janeiro \\ Nuciene Caroline Amphilóphio Fumaux \\ Lattes | carol.fumaux@gmail.com \\ Universidade Federal do Rio de Janeiro
}

Gabrielle de Figueira do Nascimento Lattes | gfigueira.nascimento@gmail.com Universidade Federal do Rio de Janeiro Thiago Moreira da Silva thiago.letras.ufrj@gmail.com Universidade Federal do Rio de Janeiro

\begin{abstract}
This paper reports on a contrastive study of Brazilian Portuguese um monte de NP and Moscow Standard Russian kucha NPgen quantifying binominal constructions, under a usage-based constructionist approach. To identify semantic specificities in both constructions, an empirical investigation based on collostructional analysis was conducted. The results indicate that despite some similarities between Portuguese and Russian in terms of cognitive operations involved in the conceptualization of the binominal quantifying constructions um monte de NP and kucha NPgen, there are specificities concerning each construction in each language in terms of semantic compatibility of lexemes co-occurring in them.
\end{abstract}

Keywords: Quantifying binominal constructions. Usage-based construction grammar. Monte. Kucha. Collostructional analysis. 
Resumo: Este trabalho consiste em um estudo contrastivo das construções binominais quantificadoras um monte de SN, do português brasileiro, e kutcha SNgen, do russo, em uma perspectiva construcionista baseada no uso. Para identificar especificidades semânticas em ambas as construções, foi realizada uma investigação empírica baseada em análises colostrucionais. Os resultados indicam que apesar de algumas similaridades entre português e russo em termos de operações cognitivas envolvidas na conceptualização das construções binominais quantitativas um monte de SN e kucha SNgen, há especificidades relativas a cada construção em cada língua no que se refere à compatibilidade dos lexemas que nelas ocorrem.

Palavras-chave: Constuções binominais quantitativas. Gramática de construções baseada no uso. Monte. Kutcha. Análise colostrucional.

\section{Introduction ${ }^{1}$}

One of the most interesting phenomena in natural language concerns the ability of some linguistic expressions to convey new meanings and/or functions over time in several domains. A number of scholars under the grammaticalization framework have already demonstrated paths of change ranging from lexicon to grammar. In order to cite one example, Bybee (2010, p. 199) supports such lexicon-to-grammar paths through a diachronic analysis of periphrastic future with will in English, reinforcing the importance of crosslinguistic comparison to understand mechanisms underlying language change.

The fact that (new) forms may be associated to new functions is observed in several domains, including quantification manifested in binominal constructions (TRAUGOTT, 2008; ALONSO, 2010; BREMS, 2012; VERVECKKEN, 2015; RAKHILINA, 2009, among others). A large group of nouns within quantifying binominal constructions - such monte ('heap'), chuva ('rain'), in Portuguese, or kucha ('heap'), morie ('sea'), in Russian - could be included in the class of quantifiers. Thus, a point to be considered is that not only classical quantifiers (such as liter, kilo, etc.) can be part of the fixed portion of such a construction.

Comparison among languages demonstrates that it is possible to make use of concrete referents to talk about abstract concepts that are related to subjective judgements of quantity (in terms of small or large quantity). That is the case of monte ('heap') which shows up within a binominal construction, i. e., um monte de NP to indicate 'a big amount

\footnotetext{
1 This paper congregates the main preliminary results of a more comprehensive research project regarding binominal constructions in different world languages, with special attention to Brazilian Portuguese.
} 
of something' in contemporary Brazilian Portuguese, a Romance language, as well as kucha ('heap') which was recruited in Russian, a Slavic language, as the fixed element instantiating the quantifying binominal construction kucha NPgen.

In this work, we are interested in the comparability between functionally similar constructions in Brazilian Portuguese and Moscow Standard Russian (hereinafter referred simply as Russian) and the crosslinguistic relevance of this analysis to a usage-based framework. We assume that, first, the comparison among different languages can reveal cognitive motivations underlying surface linguistic structure and, second, binominal constructions provide good evidences for that.

The main purpose here is to offer the results of a contrastive collostructional analysis of quantifying binominal constructions in Brazilian Portuguese and Russian following Gilquin (2015), whose work demonstrated the feasibility of such methodology applied crosslinguistically. Differently from Gilquin (2015), our focus relies not only on constructions which are semantically equivalent at first glance, but on the comparison of constructions displaying a relevant degree of productivity ${ }^{2}$ in each language. That seems to be the case of um monte de NP and kucha NPgen, since both, despite dissimilarities in terms of semantic traits, display high levels of entrenchment, with high extensibility and token frequency. In addition, while Gilquin is interested in academic writing, we focus on a more comprehensive type of writing such as the journalistic genres.

This paper is basically divided threefold: first, we will discuss collostructional analysis family of methods under a usage-based consructionist approach; second: we will analyze Portuguese and Russian separately, focusing on the results of a collexeme analysis for um monte de NP (Portuguese) and kucha NPgen (Russian). Third, we will briefly show the results obtained by the distinctive collexeme analysis for um monte de NP and kucha NPgen.

\section{Quantifying Binominal Constructions: a collexeme analysis}

This section aims at providing a brief discussion of the quantifying binominal construction associated to the methods of collostructional analysis often employed under a usage-based constructionist perspective on language. The next subsection discusses the way the quantifying binominal construction is understood under a usage-based constructionist perspective, which conceive language as a network of interrelated constructions, as form-function pairings. Subsection 2.2 shows how the specific collostructional analysis methods of collexeme and distinctive collexeme analysis were applied in this investigation.

\footnotetext{
${ }^{2}$ For more details about productivity, see Barddal (2008).
} 


\subsection{Quantifying binominal constructions and the collostructional analysis methodology}

Quantifying Binominal Constructions congregate a different set of form-meaning pairings coined in a number of languages as grammatical alternatives for quantifying referents. They frequently perform a figurative function due to the assumption that speakers' recruitment of non-quantity nouns to instantiate a quantifying construction reveals the nature of the cognitive processes (such as metaphor or metonymy) underlying the surface syntactic structure.

This analysis assumes a usage-based perspective on language and the understanding of grammar as a construction network (see GOLDBERG, 1995, 2006, 2019; DIESSEL, 2019). Since it is a functional-cognitive approach, it points out that the close relationship between semantic-pragmatic and morphosyntactic aspects of the language units will be considered here.

Assuming a constructionist approach to language, we will follow the network configuration which can be found in the background illustrated in the figure 1 below, quoted from Traugott and Trousdale (2013, p. 17) as reference for the levels of constructions schematicity.

Figure 1 - Gradience of hierarchic relationships among constructions

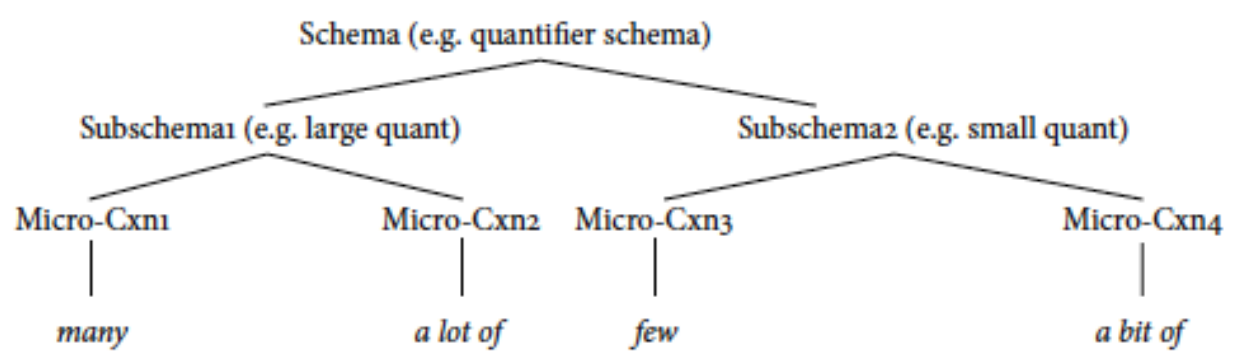

Figure 1 brings out the quantifier schema to English, reinforcing the constructionist crucial argument in favor of the arrangement of constructions in a network. Thus, it illustrates nodes and links among quantifying constructions, focusing on taxonomic links (see GOLDBERG, 1995 and DIESSEL, 2015, 2019 for a more detailed range of constructions links). In this paper, both Brazilian Portuguese and Russian analysis address selected binominal micro-constructions (e.g. um monte de NP, for Portuguese, and kucha NPgen, for Russian) assumed as nodes linked to the sub-schema 1 (large quantity).

Considering that both [um monte de NP] and [kucha NPgen] constructions display a fixed slot - um monte de and kucha, respectively - and a schematic slot requiring 
NPs without specification on declension (as in Portuguese) or NPs inflected in genitive case (as in Russian), one of the researcher's tasks is to identify what kinds of lexemes can fill the NP schematic slot in each language. According to the general principles of Construction Grammar approach, the candidates to fill the open slot in the quantifying binominal construction would exhibit some kind of semantic compatibility to the construction, that is, a word may occur in a given construction if its meaning is compatible with the meaning of the construction (cf. STEFANOWITSCH; GRIES, 2003, p. 99). Thus we would expect that in um monte de NP and kucha NPgen constructions, in addition to quantifiable referents, would attract lexemes whose referents could be arranged in large quantity so that they form a concrete or abstract (metaphorical) heap. In the case of um monte de NP construction, due to its development in the history of Brazilian Portuguese, resulting in an expressive semantic expansion of the construction regarding the semantics of the candidates to fill the open slot (cf. FUMAUX, 2018), a question may be raised: what are the collocational preferences of um monte de NP construction, considering this semantic expansion. The identification of collocational preferences may provide some insights on the status of the construction in a given synchrony.

A crosslinguistic analysis of the quantifying binominal construction mentioned above may reveal interesting points concerning quantification in language and the cognitive processes which it involves. Based on this assumption, we use quantitative methods applied to corpus analysis, which may constitute a powerful tool in studies under a usage-based constructionist perspective.

\subsection{Collostructional analysis as a feasible method to understand constructions' semantic properties}

In this paper, in order to understand some specific semantic aspects of the constructions under analysis in Brazilian Portuguese and Russian, we have used collostructional analysis - a family of association measures methods, including: (i) a simple collexeme analysis, which measures the force of attraction of lexemes to one slot in a given construction; (ii) a distinctive collexeme analysis, which measures the force of attraction of lexemes to one slot in two or more constructions; (iii) a covarying collexeme analysis, which measures the force of attraction of lexemes to two slots in one construction (see GRIES; STEFANOWITSCH, 2004, for more details).

In order to analyze the force of attraction of lexemes to the um monte de NP construction in Brazilian Portuguese and to kucha NPgen in Russian, we have recurred to a 
simple collexeme analysis for each language separately. Likewise, to compare the force of attraction of lexemes in both constructions, a distinctive collexeme analysis was applied. The covarying collexeme analysis was excluded from this research. According to Gries and Stefanowitsch (2004), in constructionist approaches the combinations of lexemes occurring in construction slots is conceived in terms of semantic compatibility. For the authors:

\begin{abstract}
A word may occur in a given construction if its meaning is compatible with the meaning of the construction; it may 'alternate' between two constructions if (or to the degree that) the word's meaning is compatible with meanings of both constructions. In the context of alternating pairs, a focus on constructional semantics and semantic compatibility raises several questions: first, what exactly are the (often seemingly tenuous) semantic differences between the members of such a pair; second, how productive is the 'alternation' in actual usage, i.e. which verbs/nouns occur freely in both constructions and which have strong biases towards one of them and third, is a constructional, non-derivative approach plausible given the answers to the first two questions. (GRIES; STEFANOWITSCH, 2004, p. 99).
\end{abstract}

Considering the questions raised by Gries and Stefanowitsch (2004), we seek to understand which lexemes are compatible with the constructions studied in this research, in order to understand a little bit more about these constructions as pairning of form and meaning. Also, we aim to identify similarities and differences between them. In order to do that, first we proceed to a simple collexeme analysis carried out separately for um monte de NP as well as kucha NPgen constructions. This kind of analysis considers (i) the size of the corpus (in number of words); (ii) the token frequency of the construction in that corpus; and (iii) the token frequency of each lexeme in the construction in order to obtain the force of attraction of each lexeme in each of the analyzed constructions (for more details, see GRIES; STEFANOWITCH, 2004; GRIES, 2014).

In order to make a feasible comparison between the two languages, we had controlled the sample data for each one. As this is a preliminary study aiming at verifying the compatibility of a collostructional analysis to the object being investigated, we started from a limited sample. As for Brazilian Portuguese data, we have considered a 35,699,765 word subcorpus of journalistic writing sampled from the basis of Linguateca (www.linguateca.pt), covering data from 1994 to 1995 of Folha de São Paulo newspaper. By this analysis, we have collected a total of 296 instances of um monte de NP. As for Russian data, we have considered a 33,547,720 words subcorpus of journalistic writing custom- 
ized on the basis of Russian National Corpus (available at www.ruscorpora.ru), covering data from 2007 to 2010 of Trud newspaper. 391 instances of kucha NPgen were collected.

In the analysis, the $\mathrm{R}$ software for statistical computing was employed in its 3.5.3 version, as well as the R Studio, a more "user friendly" software, in its open source version, available at www.rstudio.com/products/rstudio/. After downloading both softwares, a collexeme analysis was performed, using R Studio software and the script (http://www. stgries.info/teaching/groningen/readme.txt) made available by Stefan Gries at http:// www.stgries.info/teaching/groningen/readme.txt. We ran the program providing the required information specified above, that its, the subcorpus total number of words, the token frequency of the construction under analysis and the token frequency of each lexeme co-occurring within the construction (the token frequency is provided by elaborating an Excel file with a $2 \times 2$ table indicating the number of times that each lexeme is found in the construction and the overall occurrences of each lexeme in the corpus. After processing the collected data, the software provides the collostructional strength of each lexeme in relation to the analyzed construction. The greater the colostrutional strength, the greater the level of lexeme attraction for construction. When the analysis is performed, a Fisher's exact test - a statistical significance test for contingency tables - is applied, in order to verify the statistical significance of the obtained results. The significance $\mathrm{p}$-value is provided for the whole contingency table independently of the number of rows ${ }^{3}$.

After performing the collexeme analysis for each construction, we proceed to a distinctive collexeme analysis of both constructions in Brazilian Portuguese and Russian, which considers their token frequency and the lexemes occurring within them. As in this paper we are comparing similar constructions in two different languages, we followed the methodological steps proposed by Gilquin (2015) to the analysis of causative constructions with make in English and faire in French. So, we had created an Excel file containing each token of [um monte de NP] construction and each token of [kucha NPgen] construction. To have a common basis for comparison, we used the translations of Russian lexemes to Portuguese as input for the analysis. The distinctive collexeme analysis considers only the token frequency of each construction and the token frequency of each lexeme occurring in each construction. As in collexeme analysis, the distinctive collexeme analysis provides significance $\mathrm{p}$-value for the whole contingency table independently of the number of rows.

In the next section we provide a brief description of quantifying binominal constructions in Portuguese and Russian, with special emphasis for the um monte de NP and

\footnotetext{
${ }^{3}$ In order to know more about Fisher's exact test of significance, see Levshina (2015).
} 
kucha NPgen constructions, presenting a separate simple collexeme analysis for both constructions.

\section{Quantifying binominal constructions in Brazilian Portuguese and Russian}

In this section, we provide a description of binominal constructions in Portuguese and Russian, giving special attention to um monte de NP construction in Brazilian Portuguese and kucha NPgen in Russian, which yield a large number of instances in each of the respective languages. In addition, the results of a simple collexeme analysis for Portuguese and Russian are presented and discussed.

\subsection{The case of Brazilian Portuguese um monte de NP}

Binominal constructions like NP1 of NP2 can be used to quantify referents. To briefly discuss that, take the examples below, which illustrate some usages directly related to quantifying binominal micro-constructions in Portuguese:

(1) Comprei uma dúzia de ovos.

buy a dozen of eggs

'I bought a dozen eggs.'

(2) Acabou de passar uma dúzia de crianças ali. finish of pass a dozen of children there 'Just passed a dozen children there.'

(3) Terá um monte de gente na rua amanhã. have a heap of people in the street tomorrow 'There will be crowds of people on the street tomorrow.'

Considering the semantics of the examples listed above, a question that arises is about its source. We could say that the source of quantity interpretation of the these examples is basically twofold: conventionalized usages whose quantifying meaning is expressed by a more canonical quantifier (examples 1 and 2); conventionalized usages whose quantifying meaning is obtained by a quantifying inference from a prior non-quantifying usage, as we see in example 3.

In examples 1 and 2, the noun dúzia ('dozen'), which refers to a very specific amount of something, fills NP1 slot in the construction. Other quantifiers could be inserted in this set such as grupo ('group') which also implies necessarily quantity interpretation, 
but not as precisely as dúzia does, since groups can vary in relation to numbers of their members. Despite this difference, what all of those nouns fitting NP1 slot (i.e. dúzia, quilo and grupo) have in common is the fact that they can be considered typical quantifiers in Portuguese, since they can be associated to quantity meaning throughout all Portuguese constructions they can be fitted with.

Example number 2 can be interpreted in Portuguese in two different ways. Firstly, it means that exactly twelve children have passed there, and then it would be considered an instance of the quantifying binominal construction. Secondly, and apparently much more frequently, example 2 means that an indeterminate (usually, expressing hyperbolic sense to a certain amount or a rough quantity of something and presenting a stress on NP1) number of children have passed there. In this case, the meaning seems to be derived from an invited inference from the quantifying binominal construction that matches the first interpretation.

Example 3 differs from those just mentioned due to the fact that it did not function as quantifiers in the past synchronies of Portuguese. Monte ('heap') was not originally used within a quantity construction neither functions as quantifier primarily but allows a quantity inference towards a metaphorical process. Portuguese, as many other languages, seems to conventionalize quantification in terms of scales (such as monte) as a good way to express quantity meaning, including those usages within binominal constructions.

Indeed, Brazilian Portuguese offers a large group of non-canonical quantifiers showing up within quantifying binominal micro-constructions. As partially mentioned before, nouns such as monte ('heap'), mar ('sea'), enxurrada ('flash flood'), nuvem ('cloud'), tempestade ('storm') illustrate how diverse is the set of nouns which are entrenched in a quantifying binominal construction, such as (Det) monte de NP, (Det) mar de NP, (Det) enxurrada de NP, (det) nuvem de NP, (Det) tempestade de NP. Thus, the whole schema highlights the multi-word chunk, i.e., the part of the micro-construction which is often repeated and made up of a neuromotor routine (BYBEE, 2006).

Quantifying binominal constructions in Brazilian Portuguese have already been studied by other linguists (ALONSO, 2010; BRODBECK, 2010; FUMAUX, 2018; TAVARES, 2014). Based on a corpus analysis, Alonso (2010) presented some formal and semantic-pragmatic properties of Brazilian Portuguese quantifying binominal constructions. Considering her findings, the constructions to be analyzed here can be, to some extent, associated to the "multiplexing" process, defined by Talmy (2006) as an operation in which "an original solo referent is, in effect, copied onto various points of space or time" (TALMY, 2006, p. 79). 
Taking the multiplexing process into account, usages such as um grupo de pessoas ('a group of people') are typical cases associated to it, since 'group' implies the idea of the existence of various copies of something. In this case, a certain number of people corresponding to a group, which refers necessarily to more than one person, probably more than three. In addition, group frequently occurs when NP2 is a countable noun, what favors the multiplexing interpretation.

Alonso argued in favor of the idea that multiplexing process yields a large number of instances of the quantifying binominal construction, including those that express more subjective evaluations of quantity. Referents such as monte (lit. 'heap') implies quantity interpretation, which is construed more subjectively (individually).

Constructions vary in terms of degrees of entrenchment and, as far as quantifying binominal constructions are concerned, a good test to measure how entrenched the parts of the constructions are is to verify if they work separately in a given linguistic context. Considering examples such as Ela comprou um quilo de açúcar (lit. She bought a kilo of sugar/ 'She bought a pound of sugar'), um ('a') can be individually a good answer to the question How many pounds of sugar did she buy? The same is not true to examples like Há um monte de cadeiras aqui (lit. There is a heap of chairs here/ 'There are a lot of chairs here'), since considering the question How many chairs are there here?, the answer must be um monte. Separately, um as the answer to the former question creates an ungrammatical structure.

Specifically related to the subject of this section, Fumaux (2018) described the process of constructionalization (TRAUGOTT; TROUSDALE, 2013) of um monte de NP in Portuguese. In this case, differently from Figure 1, quoted from Traugott and Trousdale (2013, p. 17), the open slot - NP - is now being considered, because of the crucial role played by the second NP in the construction representation through the history of Portuguese. It bears pointing out that the architecture of an emergent grammar is shaped by use and then synchrony must not be sharply separated from diachrony. This line of investigation, then, seeks to explain how language use shapes grammar.

The discussion presented by Fumaux (2018) about the formation of the Portuguese quantifying binominal construction um monte de NP is guided by the following basic question: How did um monte de NP become a construction through the history of Portuguese? To answer the question just pointed out, let's analyze the examples below: 
(4) Um monte de Lisboa.

A heap of (loc.) Lisbon

'A heap in Lisbon.'

(5) Um monte de coisas.

A heap of things

'A lot of things.'

On one hand, example 4 represents a very typical instance of the specifying interpretation of the binominal construction, in which um monte de NP leads to a more compositional interpretation, i. e., a heap in Lisbon. On the other hand, example 5 could not be interpreted in the same way. In this case, the meaning of the whole formation is not the sum of the meaning of each part of it, but the idea of much/many of something.

Indeed, based on corpus analysis, we could consider that initially the most prominent usage of um monte de NP leads to the interpretation that usages such as um monte de Lisboa meant, and, in fact, it still means a heap in Lisbon, that is, a heap belongs to Lisbon. Besides that, other usages of monte within the specifying binominal construction yielded metonymic inferences, such as um monte de neve (a heap of snow / a lot of snow). Fumaux (2018) argued that inferences like that triggered the constructionalization process. Assuming these cases as the source of constructionalization, we should consider that in examples like that monte maintains the semantic traits of a heap (geological formation), and so the binominal construction recruits preferably nouns which make reference to natural elements, such as snow or sand, whose meanings are well accommodated to the meaning of the other parts of the construction, exhibiting, thus, a high level of compositionality.

Over the centuries, the syntagmatic string um monte de NP became gradually more frequent and increased its range of collocations with nouns from different natures instantiating NP slot. So, it undergoes increase of type frequency. In this case, what we observe from data analysis is a gradual decrease of compositionality and the formation of a chunk.

According to Fumaux (2018), um monte de NP specifying binominal construction has undergone a gradual loss of the occurrence of intervenient elements (affecting analyzability) within the construction, a gradual fixation of the indefinite article as the preferable determinant of monte, an increase of countable nouns instantiating the construction (second noun typically occurs in the plural) and a gradual change of the head of the construction. Consequently, a new construction emerges, i.e. a quantifying binominal construction um monte de NP. 
Fumaux (2018) argued in favor of the emergence of a quantifying binominal construction - um monte de NP - adding a node in the schema of quantifiers in Portuguese. She points out that um monte de NP undergoes change in meaning (quantification) and form, considering that monte initially instantiated a more compositional construction $[[\mathrm{NP}]$ of NP] and then the syntagmatic string um monte de NP was neoanalyzed and monte came to be part of a new chunk - [um monte de [NP]]. The results found in Fumaux (2018) lead to the interpretation that um monte de NP is a quantifying construction which exhibits a high level of entrenchment and has at first glance few restrictions in terms of the lexemes it recruits.

Changing of head can be considered a crucial argument to argue for the emergence of a new construction (quantifying construction) and will be detailed in another text, being structurally supported by evidences such as the following: instances such as um monte $_{\text {masc.s. }}$ de pessoas ${ }_{\text {pl fem. }}$ (lit. 'a heap of people' / 'a lot of people') are anaphorically recovered by elas (them pl.fem. $_{\text {. }}$ ) instead of by ele (lit. 'he'/ 'it'); the whole string um monte can be substituted by a degree word like muito ('much'); verb agrees preferably with pessoas, instead of with monte. However, there is no sufficient evidence to affirm that um monte de NP completely ran its turns yet.

Another potential argument, which was not provided by Fumaux's results due to the fact that some quantifying micro-constructions entrenched referents such as enxurrada (flash flood), which apparently have been recruited by a more schematic quantifywing binominal construction - $[\mathrm{NP}$ of $[\mathrm{NP}]]$ - since the unique interpretation yielded from that binominal construction instantiated by enxurrada was the quantifying one. We defend that the recruitment of enxurrada would have been motivated by analogy and enabled by the coercion of the already existent quantifying binominal construction upon the lexeme.

Although Fumaux's research has already provided very good insights concerned to that subject, we believe that the methodology offered by collostructional analysis can take another step forward on what we know about the collocational preferences of um monte de NP in Portuguese and what it reveals about the cognitive representation of the construction in the speakers' mind.

The above considerations lead us to conduct a collexeme analysis to verify which lexemes are preferably recruited by um monte de NP. Table 1 below provides the results that point out to the top ten lexemes attracted to the micro-construction um monte de NP in Brazilian Portuguese. 
Table 1 - Collexeme analysis of um monte de NP micro-construction.

\begin{tabular}{|l|c|c|c|c|}
\hline Word & $\begin{array}{l}\text { Freq. in } \\
\text { Corpus }\end{array}$ & Freq. in Cx & Expect. freq. & $\begin{array}{l}\text { Collostructional } \\
\text { strength }\end{array}$ \\
\hline Gente $^{4}$ & 5323 & 46 & 0.0441 & 121.7839 \\
Coisas_coisa $^{5}$ & 17475 & 38 & 0.1449 & 77.7477 \\
Dinheiro & 14177 & 7 & 0.1175 & 10.2862 \\
Caras & 724 & 4 & 0.0060 & 10.2812 \\
Amigos & 3611 & 5 & 0.0299 & 9.7245 \\
Cretinos & 22 & 2 & 0.0001 & 7.8007 \\
Saquê & 47 & 2 & 0.0003 & 7.1305 \\
Bandas & 1297 & 3 & 0.0108 & 6.6923 \\
Besteiras & 80 & 2 & 0.0006 & 6.6647 \\
Mentiras & 188 & 2 & 0.0016 & 5.9197 \\
\hline
\end{tabular}

Coll.strength $>3=>p<0.001$; coll.strength $>2=>p<0.01$; coll.strength $>1.30103=>p<0.05$.

Analyzing the lexemes presented in Table 2, we can observe that, although different items can be attracted by the construction, gente (people) and coisa(s) (thing(s)) shows the highest rates of collostructional strength in comparison to the others. These results corroborate the considerations pointed out by Fumaux (2018), since um monte de NP can be mostly combined with lexemes that present no semantic coherence with the idea of a monte (heap). In addition, collexeme analysis revealed that items such as gente and coisa(s) are very strongly attracted by the construction. Such collexeme-analysis findings allow us to suggest that um monte de NP is associated to the quantification of more generic referents, whatever their nature. The examples below illustrate such cases:

(9) Esse tipo de trabalho éótimo, pois você sente que tem um monte

This kind of work is great because you feel that have a heap

de gente no mundo inteiro preocupado com as mesmas coisas que você.

of people in the word all worried with the same things that you.

'This kind of work is great because you feel like there are a lot of people around the world worried about the same things that you do.'

(10) Descobri um monte de coisa naquele verão.

discovered a heap of thing in that summer.

'I discovered a lot of things in that summer' 
(11) Um monte de coisas acontecem aqui, mas são muito bem camufladas.

A heap of things happen here but are very well camouflaged.

'A lot of things happen here but they are very well hidden.'

The collexeme analysis to um monte de NP was a very important tool on the understanding of how language usage impacts constructions in terms of mental representation. While the idea of quantity of the first uses of um monte de NP were more contextually dependent and associated to invited inferences triggered by semantic mismatching (FRANCIS; MICHAELIS 2003). Thus, the diachronic analysis took the semantic coherence between monte and NP in consideration. In the contemporary Brazilian Portuguese, the analysis of um monte de NP micro-construction goes in a different direction, though. Collexeme analysis for current Brazilian Portuguese demonstrates the relevance of describing the semantic coherence among exemplars fitting SN slot, since on one hand the idea of a heap (considering a quantifying binominal construction) seems not to be available anymore and, on the other hand, most of the top ten lexemes are more generic referents.

In the next section, we will present an overview about quantifying binominal constructions in Russian followed by the results of a collexeme analysis applied to kucha NPgen.

\subsection{The case of Russian kucha NPgen}

As well as in Portuguese, in Russian the variety of nouns used for quantification is very expressive. According to Rakhilina (2009, p. 353) these nouns constitute a class of about thirty lexical items. A few interesting examples of such nouns are the lexemes kopna (haycock), gora (mountain), morie (sea) and kucha (heap), which originally mean entities that may be found in nature. Often, they don't function as predicates themselves exhibiting relational function but as predicate arguments, functioning as a head, e. g., bolshaia kopna ('big haycock'), vysokaia gora ('high mountain'), sinieie morie ('blue sea') and krasivaia kucha ('beautiful heap').

However, when occurring in the genitive binominal construction (NP NPgen), such nouns may assume a predicate or relational function, being reinterpreted as quantifiers, by means of semantic coercion. In those cases, the noun itself doesn't designate an entity, as it originally did, but express a big quantity of a thing - and in a few cases, a small one (see kaplia, 'drop', RAKHILINA, 2009, p. 350). So, the above-mentioned lexemes kopna, gora, morie and kucha, as well as many other nouns in Russian may instantiate the NP NPgen construction - as in kopna NPgen; gora NPgen; morie NPgen and kucha NPgen, 
respectfully - to express a big quantity of something.

While nouns as kopna, gora, morie and kucha may be used in a quantifying binominal genitive construction, being related to the sub-schema of large quantity, the quantity itself expressed by those nouns is permeated by qualitative nuances indicating subtle semantic differences among them, in terms of which items they can be combined with. Such subtle differences may be an evidence that such combinations as the above-mentioned kopna NPgen, gora NPgen, morie NPgen and kucha NPgen may be considered more specific constructions in the constructional network of quantifying binominal constructions in Russian and from now on they will be called here micro-constructions, according to Traugott and Trousdale (2013) terminology mentioned before.

In a work in progress, we have empirically observed through corpus analyses that although gora may be combined with a number of different referents in the quantifying genitive construction, it tends to quantify more frequently solid entities that may be grouped together to form a big mass of something, whereas morie is more often used to quantify uncountable and abstract entities like pleasure, joy and other emotions. Kucha as well as gora may be combined with a lot of nouns designating different referents, but according to Levontina (2004) there is some kind of difference between these two: while kucha refers to elements which are messily grouped together, gora refers more to the form and the extension of this grouping of elements. Kopna in turn displays semantic constraints on the elements that may be used in the quantifying genitive construction, allowing only a few numbers of items to co-occur with it. The following examples illustrate these assumptions:

(12) on khudoshav-ogo tieloslozheni-a is kopnoi sedykh volos na golovie. $3 S$ thin-GEN build-GEN and with haycock gray-GEN hair on head-PRE 'he is of thin build and with a shock of gray hair on his head.'

(13) ona stoia-l-a u plity, vypeka-ia gor-u blin-ov.

3S.F stand-PST-F at stove bake-GER mountain-ACC pancake-GEN.PL 'she stood at the stove, baking a mountain of pancakes.'

(14) Kazhdy zanial ogromnuiu nichu v moiei zhizni, ostavil morie emotsii. Everyone occupied huge niche in my life left sea emotions-GEN 'Everyone occupied a huge niche in my life, left a sea of emotions.'

(15) ... kucha narod-u sidit po tiurmam ni za chto.

heap people-GEN be sitting prisons NEG for nothing

'... a lot of people are in prison for nothing.' 
Taking kucha in a closer detail, Rakhilina (2009) argues that this item exhibits the greatest degree of grammaticalization in comparison with other lexical items used for quantification, since it almost doesn't present constraints of combination ${ }^{6}$. From a usage-based constructionist perspective, it should be argued that the micro-construction kucha NPgen displays a high degree of entrenchment, given its productivity in terms of extensibility, so that it almost does not exhibit semantic constraints on which candidates are eligible to fill the open slot in the micro-construction. It may combine with nouns designating quite different types of referents as illustrated by the examples below:

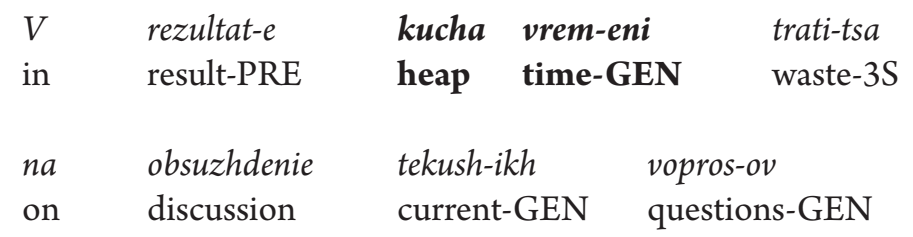

'As a result a lot of time is wasted on the discussion of current questions.'

$\begin{array}{lllll}\begin{array}{l}I \\ \text { and }\end{array} & \begin{array}{l}\text { dobavil: } u \\ \text { added in }\end{array} & \begin{array}{l}\text { parlamentar-iev } \\ \text { parliamentarians-GEN }\end{array} & \begin{array}{l}\text { kucha } \\ \text { heap }\end{array} & \begin{array}{l}\text { rabot-y } \\ \text { work-GEN }\end{array} \\ v & \text { et-om } & \text { god-y } & & \\ \text { in } & \text { this-PRE } & \text { year-PRE } & & \end{array}$

'And added: the parliamentarians have a lot of work this year.'

$\begin{array}{lllll}\text { Moi } & \text { rabotodatel } & \text { potratil kuchu dienieg na poiezdku. } \\ \text { 1POS employer } & \text { spent heap money On trip }\end{array}$

'My employer spent a lot of money on the trip.'

\begin{tabular}{|c|c|c|c|c|c|c|c|}
\hline $\begin{array}{l}\text { No } \\
\text { but }\end{array}$ & $\begin{array}{l}\text { kak } \\
\text { as }\end{array}$ & $\begin{array}{l}v y \\
2 \mathrm{PL}\end{array}$ & & $\begin{array}{ll}\text { etie } & m o j \\
\text { and-2PL poss }\end{array}$ & & $\begin{array}{l}\text { natvorit' } \\
\text { do }\end{array}$ & $\begin{array}{l}\text { kuchu } \\
\text { heap }\end{array}$ \\
\hline $\begin{array}{l}\text { bied, } \\
\text { trouble }\end{array}$ & $\begin{array}{l}\text { okaza } \\
\text { being }\end{array}$ & & $\begin{array}{l}v \\
\text { in }\end{array}$ & $\begin{array}{l}\text { chetnadtsat } \\
\text { sixteen }\end{array}$ & $\begin{array}{l}\text { liet } \\
\text { year }\end{array}$ & $\begin{array}{l}v \\
\text { in }\end{array}$ & $\begin{array}{l}\text { tuchzhoi } \\
\text { foreing-PRE }\end{array}$ \\
\hline $\begin{array}{l}\text { stranie } \\
\text { country }\end{array}$ & & $\begin{array}{l}\text { biez } \\
\text { without }\end{array}$ & & $\begin{array}{l}\text { vzroslykh } \\
\text { adults-GEN }\end{array}$ & & & \\
\hline
\end{tabular}

'But as you understand it is possible to do a lot of trouble being at the age of sixteen without adults in a foreign country.'

However, although kucha may co-occur with a great number of referents in the quantifying genitive construction, there seems to be some constraints on its co-occurrence with both liquids (kucha vody, lit. 'heap of water' / 'a lot of water', and kucha krovi, lit. 'heap of blood' / 'a lot of blood') and referents which may be metaphorized as liquids ( $k u$ -

\footnotetext{
${ }^{6} \mathrm{Kopna}$, in turn, may be use only with elements displaying some kind of visual similarity, as hair, for example, what made Rakhilina claim that this is the item with the minimum degree of grammaticalization in the quantification cline.
} 
cha udovolstvia, lit. 'heap of pleasure' / 'a lot of pleasure'), what may be saw in Li Su Hyoun (2005, apud RAKHILINA, 2009) and Rakhilina (2009). According to Li Su Hoyou hypothesis, there is some kind of semantic conflict between the homogeneity of liquids and the meaning of a messy grouping expressed by kucha, as pointed out by Levontina (2004). On the other hand, despite the claims made by Rakhilina and Li Su Hoyou about the constraints on the combination of kucha with liquids, it is possible to find real instances of this use in Russian in a search on Google, as shown in (20), (21) and (22) below:

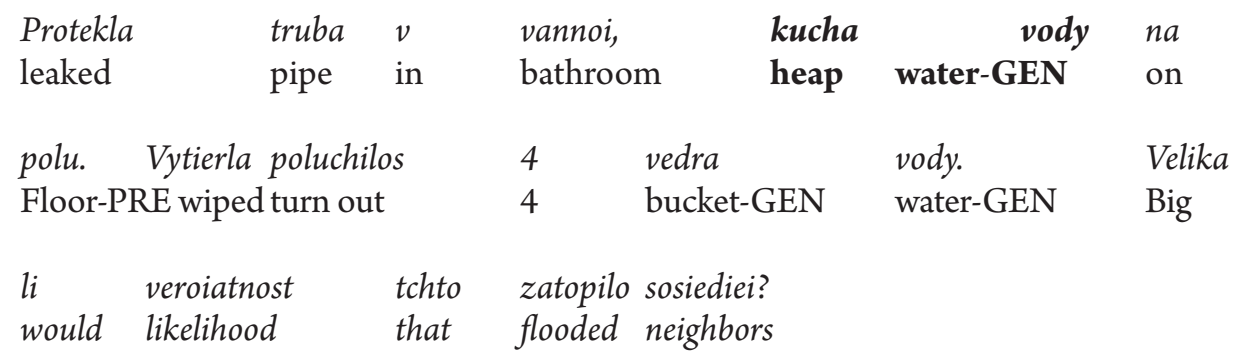

'A pipe leaked in the bathroom, there was a lot of water on the ground. I wiped and it turned out 4 buckets of water. Did I flood the neighbors?"7

$\begin{array}{llllll}\begin{array}{l}\text { Pervyi } \\ \text { first }\end{array} & \begin{array}{l}\text { opyt } \\ \text { experience }\end{array} & \begin{array}{l}\text { Golos: razbor } \\ \text { on }\end{array} & \text { golos sort } & \begin{array}{l}\text { polov } i \\ \text { flights and }\end{array} \\ \text { kucha } & \begin{array}{l}\text { udovolstvia } \\ \text { pleasure-GEN }\end{array} & & & & \\ \text { heap } & & & \end{array}$

'First experience at Golos: the sorting out of flights and a lot of pleasure.'

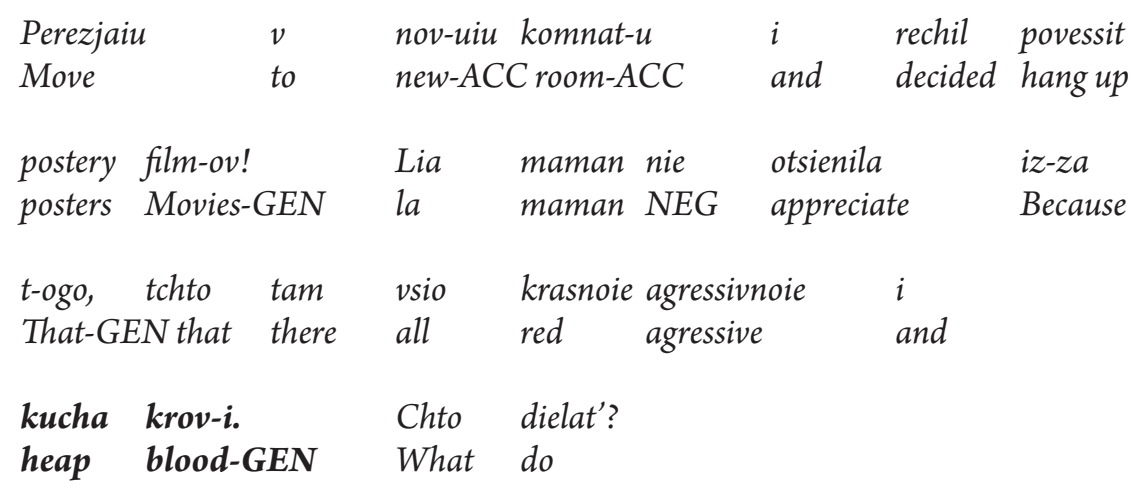

'I'm moving to a new room and I decided to hang up movie posters! La maman did not appreciate because everything is red, aggressive and there is a lot of blood. What do I do?"9

The examples (20), (21) and (22) were extracted from forums and a blog, genres reflecting a kind of relaxed everyday language, in which it was possible to find instances of such kinds of combination, differently from journalistic writing, where no such an example was found. Considering this as well as the insights provided by Rakhilina (2009),

\footnotetext{
7 https://otvet.mail.ru/question/168564015.

${ }^{8}$ https://golos.io/ru--golos/@atvalevsky/pervyi-opyt-na-golos-razbor-poletov-i-kucha-udovolstviya

${ }^{9}$ https://thequestion.ru/questions/240901/pereezzhayu-v-novuyu-komnatu-i-reshil-povesit-posteryfilmov-lya-maman-ne-ocenila-iz-za-togo-chto-tam-vsyo-krasnoe-agressivnoe-i-kucha-krovi-chto-delat
} 
we would venture to say that this lexical combination is still associated to an informal discourse reinforcing the assumption that grammar is dynamic and spreads over language use.

Considering the overview presented here for Russian genitive quantifying binominal construction NP NPgen, the specificities related to the kucha NPgen micro-construction, and also the patterns related to Brazilian Portuguese, some research questions may be raised. The first one concerns the productivity of this micro-construction. Since it is considered the more entrenched genitive quantifying binominal construction in Russian, what is in fact the extensibility of this micro-construction in journalistic writing? Is it extensible to a large group of semantic domains regarding the NPgen?

Considering this question, another one may be raised: what are the collocational preferences of kucha NPgen in journalistic writing? Is it possible to map the semantic coverage of kucha NPgen micro-construction in this discourse domain?

In order to answer such questions, we have proceeded to a collexeme analysis ${ }^{10}$ of kucha NPgen in the same vein as the collexeme analysis processed to Brazilian Portuguese above. Table 2 below provides the top ten lexemes attracted to the kucha NPgen microconstruction:

Table 2 - Collexeme analysis of kucha NPgen construction

\begin{tabular}{l|c|c|c|c}
\hline Word & $\begin{array}{l}\text { Freq. in } \\
\text { Corpus }\end{array}$ & Freq. in Cx & $\begin{array}{l}\text { Expect. } \\
\text { freq. }\end{array}$ & $\begin{array}{l}\text { Collostructional } \\
\text { strength }\end{array}$ \\
\hline diengi (money) & 1149 & 38 & 0.0134 & 116.9795 \\
mussor (garbage) & 44 & 15 & 0.0005 & 62.7590 \\
probliema (problem) & 5394 & 16 & 0.0745 & 31.5364 \\
vriemia (time) & 17551 & 15 & 0.2046 & 22.6550 \\
dokument (document) & 1426 & 9 & 0.0166 & 21.6316 \\
narod (folk) & 1237 & 8 & 0.0144 & 19.3810 \\
bumaga (paper) & 416 & 6 & 0.0048 & 16.7779 \\
rebionok (child) & 2952 & 7 & 0.0344 & 13.9854 \\
spravka (certificate) & 299 & 4 & 0.0035 & 11.2281 \\
pretenzia (claim) & 343 & 4 & 0.0040 & 10.9886 \\
\hline
\end{tabular}

Coll.strength $>3=>p<0.001$; coll.strength $>2=p<0.01$; coll.strength $>1.30103=>p<0.05$.

In terms of semantic coverage, it is possible to observe through the top ten lexemes in Table 2 that in journalistic writing the lexemes associated to the micro-construction kucha NPgen range from concrete referents that may be physically grouped together (documents, money, garbage and so on) to abstract things that not necessarily may be grouped

\footnotetext{
${ }^{10}$ As well as in the collexeme analysis of Brazilian Portuguese we considered the scrip for collexeme analysis as proposed by Gries (2014), available at http://www.linguistics.ucsb.edu/faculty/stgries/teaching/ groningen/readme.txt
} 
in space and time (probliema 'problem', kompliment 'compliment'), from mass nouns as diengi ('money') or mussor ('garbage') to count nouns as dokument ('document') or bumaga ('paper').

Although kucha can be combined with a great variety of lexical items in Russian as well as monte in Brazilian Portuguese, the collexeme analysis made for Russian reveals some kinds of collocational preferences for the kuch a NPgen construction, differing from the um monte de NP construction. In Russian journalistic writing it was possible to see that diengi 'money' displays the greatest collostructional strength, followed by mussor 'garbage', probliema 'problem', vriemia 'time', document 'document' and so on. Although the nouns associated to the micro-construction designate some kind of generic entity, the degree of specificity is much greater than in Portuguese. A brief look at the top five lexemes instantiating the kucha NPgen micro-construction reveals at least two different semantic domains: concrete things that can be stacked, as diengi, mussor and document, despite their degrees of specificity, and abstracts things that may be individuated as probliema 'problem' or divided in distinct portions as vriemia 'time'.

Differently from Brazilian Portuguese um monte de SN, kucha NPgen seems to have more semantic coherence among its members. One may ask what do problema and vriemia have in common with diengi, document and other concrete referents in order to be good candidates to instantiate kucha NPgen micro-construction. Let's look a few examples below:

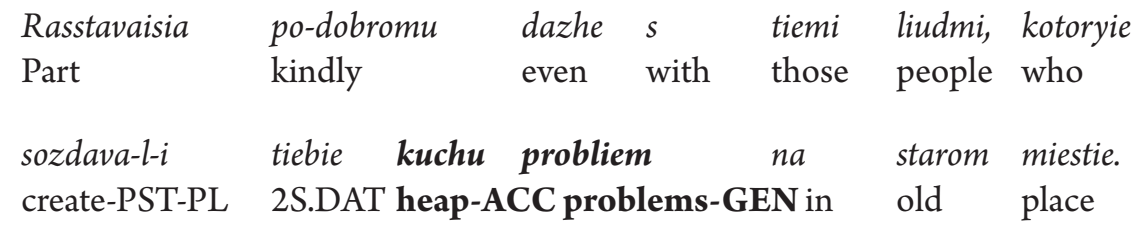

'Part kindly even with those people who created a lot of problems to you in the old place.'

$\begin{array}{lllll}\begin{array}{l}\text { Nie } \\ \text { NEG }\end{array} & \begin{array}{l}\text { khochu } \\ \text { want }\end{array} & \text { perechisliat } & \begin{array}{l}\text { kuchu probliem } \\ \text { heap-ACC problem-GEN }\end{array} & \begin{array}{l}\text { sviazannykh } \\ \text { related }\end{array} \\ \text { c } & \text { nizkoi } & \text { zarplaty } & \text { uchitielia } \\ \text { to } & \text { low } & \text { salaries } & \text { teacher }\end{array}$

'I do not want to list a lot of problems associated with poor material base, with low teacher salaries.'

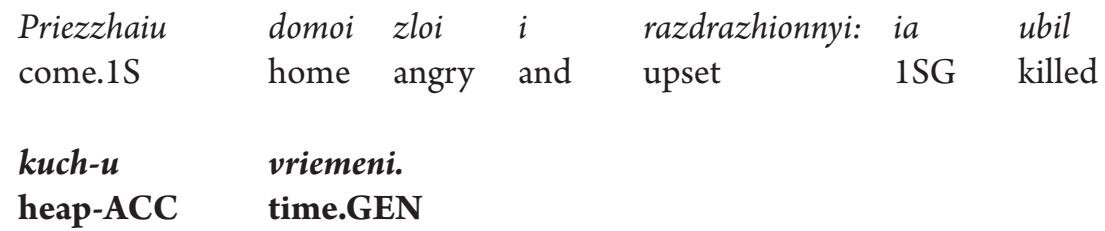

'I come home angry and upset: I've killed a lot of time.' 
(26)

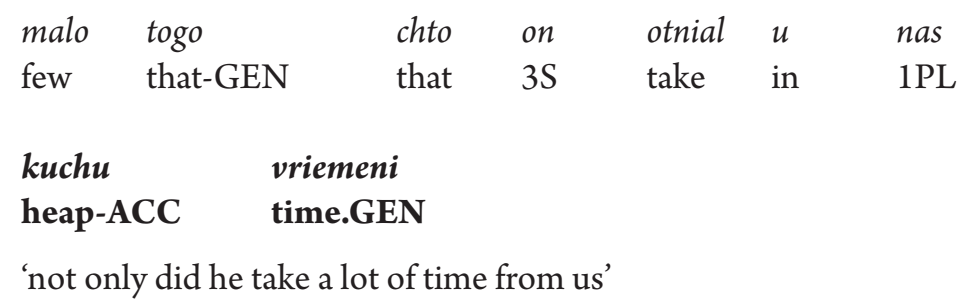

The instances presented above show that probliema 'problem' and vriemia 'time' may be metaphorized and conceptualized as entities that may be individuated, displaying some kind of materiality. According to the cognitive operation of reification as proposed by Talmy (2000, p. 43), probliema and vriemia may be reified as objects that can be grouped together in large quantities, which may be transferred or taken away. In (23) the old place (staroie miesto) represents a kind of container where problems may be located in a large amount and in (24) problems are imagined as things cluttered together that can be presented and listed. As for vriemia, in (25) time is though as a concrete thing that can be killed in some way and in (26) it is treated as something that in a way or another may be taken away from people.

In any case, analysis provided by Levontina (2004) of kucha grouping together things in a messy way applies to entities as time and problem. So, according to $\mathrm{Li} \mathrm{Su}$ Hoyoun (2005) hypothesis discussed by Rakhilina (2009), probliema and vriemia as well as diengi, document, mussor and so on designate entities that may be reunited somehow in a messy way, as empirically verified in corpus analysis. Thus, kucha NPgen semantic features can be distinguished from the other micro-constructions in a large amount sub-schema of quantifying binominal constructions in Russian.

\section{Contrasting um monte de NP and kucha NPgen: a distinctive collexeme analysis}

This section provides a comparison between Brazilian Portuguese um monte de NP construction and Russian kucha NPgen construction. Section 4.1. presents a distinctive collexeme analysis for these constructions indicating the preferences for lexemes that emerges when theses constructions are compared. Section 4.2. offer a preliminary interpretation for the results obtained through the collostructional analysis performed in this research. 


\subsection{A distinctive collexeme analysis for Portuguese and Russian Quantifying binominal constructions}

The collexeme analysis presented in the previous section were made separately for Brazilian Portuguese and Russian. Now, following Gilquin (2015), we walk toward a direct analysis between Brazilian Portuguese um monte de NP micro-construction and Russian kucha NPgen micro-construction by means of a distinctive collexeme analysis. As mentioned in section 2, the aforementioned type of analysis allows one to study one slot in two or more similar constructions. The analysis accomplished here considers the occurrences of lexemes within the um monte de NP micro-construction in Brazilian Portuguese and the translation, from Russian to Portuguese, of the lexemes occurring within the kucha NP micro-construction.

An interesting result is that out of the 364 different lexemes, 26 collexemes are shared by both constructions corresponding to a proportion of $7.14 \%$, what may represent a small overlap in terms of the semantic fields covered by the respective constructions in Brazilian Portuguese and Russian. In addition, this overlap covers concrete inanimate referents (like money, paper, letter), concrete animate referents (like friend, tourist), as well as inanimate, abstract referents (like question, action, mistake).

However, these similarities between um monte de NP and kucha NPgen constructions seem not to be as significant as their specificities. Table 3 presents the statistically relevant collexemes occurring in um monte de $S N$, shown in the upper part of the table, and kucha NPgen constructions, shown in the lower part of it. It is possible to observe that despite Russian kucha NPgen micro-construction displayed a greater token frequency, the number of statistically relevant lexemes co-occurring in each construction is relatively the same ( 6 for Brazilian Portuguese and 7 for Russian). Besides, the force of attraction of lexemes to Brazilian Portuguese um monte de NP micro-construction is relatively greater than in Russian (the difference among thing, people in Brazilian Portuguese and the preferred collexemes for Russian kucha NPgen micro-construction is considerably greater), revealing that some lexemes in Portuguese have higher force of attraction in comparison with any preferable collexeme in Russian. 
Table 3 - Distinctive collexeme analysis: Um monte de NP and kucha NPgen

\begin{tabular}{l|c|c|c|c}
\hline Lexeme & $\begin{array}{l}\text { Obs. freq. } \\
\text { Portuguese }\end{array}$ & $\begin{array}{c}\text { Obs. freq. } \\
\text { Russian }\end{array}$ & Coll. strength & Pref. occur. \\
\hline Coisa (thing) & 38 & 0 & 14.5205 & Portuguese \\
Gente (people) & 46 & 6 & 11.7034 & Portuguese \\
Cara (guy) & 4 & 0 & 1.4677 & Portuguese \\
Filme (movie) & 4 & 0 & 1.4677 & Portuguese \\
Homem (man) & 4 & 0 & 1.4677 & Portuguese \\
Mulher (woman) & 4 & 0 & 1.4677 & Portuguese \\
Dinheiro (money) & 7 & 38 & 4.3008 & Russian \\
Problema (problem) & 0 & 16 & 3.9751 & Russian \\
Tempo (time) & 0 & 15 & 3.7229 & Russian \\
Lixo (garbage) & 1 & 15 & 2.8417 & Russian \\
Documento (document) & 0 & 9 & 2.2204 & Russian \\
Povo (folk) & 0 & 8 & 1.9718 & Russian \\
Criança (child) & 0 & 7 & 1.7236 & Russian \\
\hline Colstrgth $>3$ p & 0 & &
\end{tabular}

Coll.strength $>3=>p<0.001$; coll.strength $>2=p<0.01$; coll.strength $>1.30103=>p<0.05$.

The results presented in Table 3 point to differences between Portuguese and Russian binominal quantifying constructions in terms of the preferable collexemes occurring in um monte de NP and kucha NPgen respectively. It is interesting to note that Portuguese and Russian go in different directions in terms of preferable lexemes to occur in the micro-construction. While Portuguese um monte de NP covers more generic referents as thing or people, and mostly animate referents as woman, guy or man, Russian genitive quantifying binominal construction kucha NPgen relates to mostly inanimate and less generic referents, as money, problem, and time.

\subsection{Interpreting Brazilian Portuguese um monte de NP and Russian kucha NPgen constructions}

Collostructional analysis is certainly one of the best choices if you want to capture the meaning of a construction in a corpus. In this work we could observe Russian kutcha NPgen and Portuguese um monte de NP preferable collocates, i.e. piled stuff for Russian and generic referents for Portuguese. Although those results offer a good insight about constructional meaning of each construction, it seems to be necessary to take a further step in the interpretation of them, considering their implications to the study of grammar. So, a question which arises from the results of distinctive analysis, especially when two different languages are being compared, concerns to what differences on preferable col- 
locates for Russian and Portuguese tell us about differences across languages in general.

As already demonstrated in this paper, both Russian and Portuguese quantifying binominal constructions can be associated to the cognitive process called by Talmy (2006) as multiplexing, which is a process by which different constructions affect the conceptualization of a referent, in terms of having multiple copies of it. Even though this is true, there is no guarantee that the same semantic cluster of lexemes will be preferably attracted by the quantifying binominal constructions in both languages. The reason for that relies on the dynamic development of such a language and tell us much about the close relationship between past and present on language.

Brazilian Portuguese um monte de NP construction was probably coined in the $18^{\text {th }}$ century as a result of a long span of time of change, since $16^{\text {th }}$ (at least). Fumaux (2018) observed that the spread of usages of um monte de being combined with lexemes referring to natural elements $(N P)$ as sand, straw, etc., resulted from the iconic association between the shape of a heap (monte) and the shape of a sand heap, for example. So, contexts yielding quantity inferences were frequently associated to the form um monte de NP throughout the history of Portuguese and, then, a new form-meaning pairing, i.e. the quantifying binominal construction, arose. Initially, preferable collocates for this construction were piled items and then gathered items, not necessarily piled but contiguous in space and time. In $19^{\text {th }}$ and $20^{\text {th }}$ centuries, Fumaux (2018) observed an increasing of the spread of uses of the construction and consequently a decreasing of the semantic specification of the lexemes it recruits.

Although many different clusters can be recruited by the construction um monte de $N P$ in contemporary Brazilian Portuguese, its preferable collocates correspond to more generic referents such as gente (people) and coisas (things). Assuming that it can be combined with any lexeme probably unrestrictedly, we still have to explain why generic referents instead of any other semantic cluster of lexemes are preferred by the construction.

The answer seems to be twofold: first, the increasing of instances of um monte de gente e um monte de coisa(s), which affects the mental representation of the construction and, because of that, stimulates the recruitment of new types of generic referents (eg. dinheiro/ money; caras/ guys), increasing the type frequency but lower variability. Second, the competition between constructions on language system, by which new quantifying binominal constructions were coined in Brazilian Portuguese in the $20^{\text {th }}$ century, such as uma enxurrada de NP ('a flash flood of NP', a lot of NP), uma chuva de NP ('a rain of NP', a lot of NP), uma montanha de NP ('a mountain of NP', a lot of NP). Those most recently 
coined competitor constructions preferably recruit, respectively, lexemes that are being transferred from one place to another, lexemes that are interpreted as 'bad' and lexeme referring to piled stuff, which indicates that they carry a specific meaning (by relative semantic coherence between enxurrada, chuva e montanha and the respective NP) that um monte de NP cannot express anymore. Therefore, um monte de NP would be preferably used on unmarked contexts while the others would be preferably used on marked contexts, which present a higher level of expressivity.

Concerning to Russian, since there are no studies (from the best of our knowledge) which describe the history of kutcha NPgen, we assume that as a construction recently coined on language, on the basis of the fact that its performance is closer to the newest constructions of Portuguese quantifying binominal constructions mentioned above. Kutcha NPgen preserves a relative semantic coherence between kutcha, the name taken as the quantifier, and the lexemes recruited to the NPgen slot, taken as quantified. Thus, we believe the difference between Russian kutcha NPgen and Portuguese um monte de NP preferable collocates can bring out information about time and spreading and, consequently, extensibility of constructions.

This phenomenon illustrates the dynamics of language system, revelling the different forces in action. Oldest constructions undergoes changes in their behavior as well as changes in the language system as a whole, such as the influence of how oldest and newest competitor constructions (by similarities in form or function) behave. Since time affects grammar system and thus the performance of constructions, we should consider the following issues: the newest and the oldest binominal constructions are at different stages in terms of entrenchment (the oldest constructions tend to be more entrenched than the newest ones); productivity (the oldest constructions tend to be more productive in terms of extensibility than the newest ones); semantic coherence (the oldest constructions tend to present less semantic coherence than the newest ones); spreading (the oldest constructions tend to be allowed in more contexts than the newest ones). Therefore, we should consider that, if constructions have its own history on language, the comparison between them can not put aside crucial aspects that involves the dynamic system of grammar.

In addition, we believe that um monte de NP emerged as an alternative to the existent quantifiers and could give a kind of emphasis to the quantification, but, throughout the time, it (partially) lost that capacity since it increased in frequency and decreased in terms of its semantic coherence. Thus, the newest binominal constructions are used 
today in competition with um monte de NP in contexts requiring a higher level of expressivity (pragmatically and semantically), following the Principle of Maximized Expressive Power, according to which the inventory of constructions is maximized for communicative purposes (GOLDBERG, 1995, p. 67).

\section{Conclusion}

Quantity is a basic concept for human cognition being expressed in language in various ways, and, worldwide, speakers of different languages recruit non-quantity nouns to quantify referents. In this paper, we investigated two quantifying binominal constructions - um monte de NP, in Brazilian Portuguese, and kucha NPgen, in Russian - under a usage-based constructionist approach, from a contrastive perspective.

The methodology applied to this research involves a family of methods named as collostructional analysis, which in a usage-based perspective of language has been proven to be a useful tool. In this work, we used two of those methods in order to investigate the collocational preferences of each construction in Portuguese as well as Russian: a simple collexeme analysis and a distinctive collexeme analysis.

The results obtained through those analyses reveal that Brazilian Portuguese um monte de NP micro-construction attracts preferably lexemes denoting more generic referents. As far as Russian kucha NPgen is concerned, the preferably co-occurring lexemes tends to denote not so generic entities as in Portuguese. The semantic coverage of this construction in Russian seems to be more diverse, ranging from concrete massive nouns as mussor (garbage) to abstract nouns such as probliema (problem). In addition, there seems to be a semantic difference between the micro-constructions analyzed in this paper. While Brazilian Portuguese um monte de NP seems to have lost the semantics related to heap, being associated to generic/general referents, Russian kucha NPgen seems to have preserved some features associated to the idea of a heap, designating entities that may be reunited somehow in a messy way.

Another question that can be raised concerns to how much a specific corpus is representative of language as a whole. Since we used a sample of journalistic texts, the results obtained in this work are valid to the extent it concerns to this specific discourse domain. Considering the benefits and the limitations of this work, our results show that, although Portuguese and Russian make use of metaphor and reification (see section 3 ) as cognitive operations directly associated to quantifying binominal constructions, collocational preferences demonstrate that each construction in each language exhibits semantic spec- 
ificities which highlights how use impacts construction representation, corroborating to the assumption that grammar is language-specific.

\section{References}

ALONSO, K. S. B. Construções binominais quantitativas e construção de modificação de grau: uma abordagem baseada no uso. 2010. Tese (Doutorado em Linguística) - PPG em Linguística, Universidade Federal do Rio de Janeiro, Rio de Janeiro, 2010.

BARDDAL, J. Productivity: evidence from case and argument structure in Icelandic. Amsterdam: John Benjamins, 2008.

BREMS, L. The establishment of quantifier constructions for size nouns: a diachronic study of heap(s) and lot(s). Journal of Historical Pragmatics, v. 13, p. 202- 231, 2012.

BRODBECK, R. C. M. S. Um monte de problemas gera uma chuva de respostas: um estudo de caso de desencontro na quantificação nominal em português. 2010. Tese (Doutorado em Linguística) - Faculdade de Letras, Universidade Federal de Juiz de Fora, 2010.

BYBEE, J. Language, usage and cognition. New York: Cambridge University Press, 2010.

DIESSEL, H. Usage-based construction grammar. In: DABROWSKA, Ewa; DIVJAK, Dagmar (eds.). Handbook of Cognitive Linguistics. Berlin: Mouton de Gruyter, 2015. p. 295-321.

DIESSEL, H. The grammar network: how language structure is shaped by language use. Cambridge: University Press, 2019.

FRANCIS, E. J., MICHAELIS, L. A. (Org.) Mismatch: form-function incongruity and the architecture of grammar. Stanford, CA: CSLI Publications, 2003.

FUMAUX, N. C.A. Construcionalização de 'um monte de $S N$ ': uma abordagem centrada no uso. 2018. Dissertação (Mestrado em Linguística) - PPG em Linguística, Universidade Federal do Rio de Janeiro, 2018.

GILQUIN, G. Contrastive collostructional analysis: causative constructions in English and French. Zeitschrift für Anglistik und Amerikanistik, v. 63, n. 3, p. 253-272, 2015.

GOLDBERG, A. E. A construction grammar approach to argument structure. Chicago/ London: The University of Chicago Press, 1995.

GOLDBERG, A. E. Constructions at work: the nature of generalization in language. Oxford: Oxford University Press, 2006.

GOLDBER, A. E. Explain me this: creativity, competition and the partial production of constructions: Princeton: Princeton University Press, 2019.

GRIES, S. T. Coll.analysis 3.5.: a script for R to compute perform collostructional analyses, 2014. 
GRIES, S.; STEFANOWITSCH, A. Extending collostructional analysis: a corpus-based perspective on 'alternations'. International Journal of Corpus Linguistics, v. 9, n. 1, p. 97-129, 2004.

LEVONTINA, I. B. Slovarnyie stati kucha, gora, gruda, vorokh i kipa. In: Novyi obiasnitelnyi slovar sinonimov russkogo iazyka. Moskva i Viena: Iazyki slavianskoi kultury, Vienskii slavistitcheskii almanakh, 2004.

LEVSHINA, N. How to do Linguistics with R. Amsterdam: John Benjamins. 2015.

RAKHILINA, E. Lingvistika konstruktsii. Moskva: Abukovnik, 2009.

SANTOS, C. Gramática e cognição: um estudo de construções binominais. 2014. Dissertação (Mestrado em Linguística) - PPG em Linguística, Universidade Federal do Rio de Janeiro, 2014.

STEFANOWITSCH, A.; GRIES, S. Collostructions: On the interaction between verbs and constructions. International Journal of Corpus Linguistics, v. 8 n. 2, p. 209-243, 2003.

TALMY, L. Toward a Cognitive Semantics. Volume I: Concept structuring systems. Cambridge, Massachusetts, London: The MIT Press, 2000.

TALMY, L. Grammatical construal: the relation of grammar to cognition. In: GEERAERTS, D. (Org.). Cognitive linguistics: basic readings. Berlim/Nova York: Mouton de Gruyter, 2006.

TAVARES, T. As construções binominais de quantificação indefinida: uma análise construcionista. In: Litteris, n. 4, set. 2014.

TRAUGOTT, E. C. Grammaticalization, constructions and the incremental development of language: suggestions from the development of degree modifiers in English. In: ECKARDT, R.; JÄGER, G.; VEENSTRA, T. (eds.). Variation, selection, development: probing the evolutionary model of language change. Berlin: Mouton de Gruyter, 2008. p. 219-250.

TRAUGOTT, E. C., TROUSDALE, G. G. Constructionalization and constructional change. Oxford University Press: Oxford, 2013.

VERVECKKEN, K. D. Binominal quantifiers in Spanish: conceptually-driven analogy in diachrony and synchrony. De Gruyter, 2015.

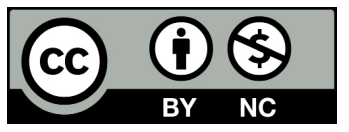

Data de submissão: 15/12/2019

Data de aceite: 05/05/2020 